\title{
The effect of continuous grazing on the seed production of Subterranean clover (Trifolium subterraneum).
}

\author{
M.L. SMETHAM ${ }^{1}$ and B.S. DEAR ${ }^{2}$ \\ 175A, Aikmans Road, Merivale, Christchurch \\ ${ }^{2}$ NSW Agriculture, Agricultural Institute, PMB Wagga Wagga, N.S.W. 2650, Australia \\ arborsand@clear.net.nz
}

\begin{abstract}
Three pure swards of subterranean clover were either (a) left ungrazed with a leaf area index (LAI) of 4.6, or (b) continuously grazed leniently to leave $1600 \mathrm{~kg}$ $\mathrm{DM} /$ ha herbage mass equivalent to an LAI of 1.0 , or (c) hard grazed to leave $1400 \mathrm{~kg} \mathrm{DM} /$ ha herbage mass equivalent to an LAI of 0.6 throughout the flowering period. These swards yielded 1250,320 and $70 \mathrm{~kg} / \mathrm{ha}$ of seed, respectively. One intensive sampling during the middle of flowering showed that seed yield was positively correlated with plant weight, leaf area per plant, and area per leaf, specific leaf area and leaf area ratio. Grazing reduced numbers of both inflorescences and burrs and hence seed yield. Whilst reduced leaf area and plant weight may have also been partly responsible, under hard grazing, only $58 \%$ of potential reproductive sites were occupied which suggests that grazing animals also reduced seed yield by consuming these.
\end{abstract}

It is recommended that continuous grazing during flowering and seed maturation should be controlled to leave at least $1600 \mathrm{~kg} \mathrm{DM} / \mathrm{ha}$ of residual herbage mass, equivalent to an LAI of 1.0, if adequate seed is to be produced to be ensure the establishment of a high producing sward in the following growing season.

Key words: flowering, grazing, herbage mass, leaf area, seed production, Trifolium subterraneum

\section{Introduction}

The annual species subterranean clover (Trifolium subterraneum) must re-establish from seed every autumn. Over the last 20 years there has been a growing awareness in Australia that many subterranean clover pastures are becoming less productive. (Carter et al. 1982). Soil acidity, root rot and low soil phosphorus are factors that have caused a decline in the vigour and density of subterranean clover in New South Wales (Hochman et al. 1990). An increase in soil $\mathrm{N}$ level as a result of growing this
$\mathrm{N}$-fixing legume, increases the competitiveness of associated broad-leaved weeds and grasses, which can impair the re-establishment of subterranean clover each autumn.

High grazing pressure, associated with the reluctance of farmers to reduce stock numbers as cereal acreage increased in the late 1970s and early 1980s (Carter et al. 1982), was probably a major factor contributing to lower productivity. Heavy grazing in spring is a frequent occurrence in years with below average rainfall (B.S. Dear unpublished data). Sheep progressively deplete seed reserves of subterranean clover by ingestion over summer and autumn (de Koning \& Carter 1989), but grazing during flowering and seed maturation also has a major impact (Collins 1978).

Defoliation up to first flower appearance generally increases seed production by up to $30 \%$, whereas defoliation after this reduces seed yield e.g. Rossiter (1961). This was found to occur even when grazing was stopped before inflorescences appeared or where the height of defoliation is raised to avoid flower removal (Collins 1978).

There are, however, few reports of research concerned with the severity of grazing over the whole period of flowering and seed maturation. Intermittent grazings in winter, early, and late spring (Conlan et al. 1994) did not affect the seed yields of two subterranean clover cultivars, but did reduce yield from 'Clare' by $50 \%$. However defoliation was never severe and left a leaf area index (LAI) of 2.7-3.4, which would not have penalised plant growth (Fukai \& Silsbury 1976). Periodic grazings at 21-52 d intervals during flowering and up to pod formation were found by Young et al. (1994) to reduce seed yield by up to $50 \%$.

The experiment reported here was designed to assess the impact of different intensities of continuous grazing over the whole period of flowering, seedset and maturation on seed production from subterranean clover. 


\section{Materials and methods}

The experiment was sited on a flat, irrigated area of poorly structured red earth soil classified as a Red Chromosol (Stace et al. 1968), at the New South Wales Department of Agriculture Agricultural Institute, Wagga Wagga, (3503'S, $\left.147^{\circ} 21^{\prime} \mathrm{E}\right)$. Lime was applied at $2.3 \mathrm{t} / \mathrm{ha}$ prior to cultivation and $400 \mathrm{~kg} / \mathrm{ha}$ of superphosphate was applied over the growing swards on 4 September 1985.

The seed was inoculated and lime-pelleted before sowing. Seed was drilled at $100 \mathrm{~kg} / \mathrm{ha}$ into a prepared seedbed on 20 June 1985 using a cone seeder with a row spacing of $0.16 \mathrm{~m}$. Plots were $3 \mathrm{~m}$ x $15 \mathrm{~m}$. A split plot design was used, with four replications. Mainplot treatments were "Nil"-no grazing; "Lenient"-moderate grazing monitored visually to leave at least one layer of leaf over the crown and runners; and "Hard"severe grazing monitored visually to leave few leaves over the crown and runners. Subplot treatments were the five subterranean clover cultivars 'Trikkala', 'Seaton Park', 'Junee', 'Woogenellup' and 'Mount Barker'.

Germination had occurred to give more than 1000 seedlings $/ \mathrm{m}^{2}$ in all plots by 31 July. Plants produced one to four trifoliate leaves by 4 September. All plots were irrigated with $150 \mathrm{~mm}$ water on 27 September. By 3 October an estimated $50 \%$ of 'Seaton Park' plants were flowering, while only $1 \%$ of 'Trikkala', 'Woogenellup' and 'Junee' plants had flowers and 'Mount Barker' had none.

On 3 October, mature Merino wethers were introduced to the mainplots to impose set-stocked grazing treatments. Over the next 3 weeks a visual assessment of the levels of defoliation being achieved was made every 2 or 3 days. By 22 October the desired levels of defoliation were reached and stocking was continued at much the same level, with adjustments when necessary, until 15 December. At this time all plots had lost all green colour, herbage was desiccated, and stock were withdrawn. Stocking rates during the treatment period averaged 45 wethers/ha for the 'Lenient' treatment, and 90 wethers/ha for the 'Hard' treatment.

On 1 November $150 \mathrm{~mm}$ of water was applied to the experimental area on 1 November, and from 15 November irrigation was carried out every four to five days to maintain soil moisture above wilting point until leaf appearance of the latest flowering cultivar, 'Mount Barker', ceased on 15 December.

\section{Measurements}

The methodology involved sampling the plant growth response intensively on one occasion, during the setstocked treatment period, in order to link these data with seed production measurements taken in late summer.

Ungrazed treatments were sampled on 23 October, and both grazed treatments were sampled on 25 October. All herbage was cut to ground level within four 100 $\mathrm{mm} \times 100 \mathrm{~mm}$ quadrats positioned at random on rows within each plot. The numbers of plants, leaves, inflorescences and burrs in each quadrat were counted, and the total length of runners in each quadrat was recorded. Leaf area per quadrat was measured by passing the leaves harvested through an airflow planimeter. All plant material was dried at $70{ }^{\circ} \mathrm{C}$ for 48 hours. Total herbage and leaf mass were recorded separately.

On 25 February 1986 all plots were sampled to measure seed reserves on and in the soil, using a tractor mounted scoop $100 \mathrm{~mm}$ wide to cut a trench $30 \mathrm{~mm}$ deep by $2 \mathrm{~m}$ long. Seed was recovered from these samples by an initial wash to remove soil, drying at $40{ }^{\circ} \mathrm{C}$ for 24 hours, threshing with a rubber paddle rotary beater, sieving to remove plant trash, and finally, flotation in saturated zinc sulphate solution to remove stones before a final washing and drying.

\section{Data analysis}

Data was subjected to analysis of variance using Genstat V (Lawes Agricultural Trust, 1984). The design of the experiment included an extreme treatment (no grazing), which caused large differences in variance between treatments. Therefore all data were square root or logarithmic transformed before analysis of variance. The results show however that this failed to solve the problem completely. The figures shown in Tables 1-3 are all back-transformed values, but where appropriate means separation based on least significant difference tests of the transformed data are presented. Although analysed, the results for individual cultivars are not reported here, except to state that there were no significant differences in seed production between them, and no interactions. The results quoted are therefore means across all cultivars.

\section{Results}

At the time of intensive sampling, grazing had reduced $(\mathrm{P}<0.01)$ the herbage mass from $5587 \mathrm{~kg} \mathrm{DM} /$ ha for 
the Nil treatment (Table 1) to 1613 and $1405 \mathrm{~kg} \mathrm{DM} /$ ha for the 'Hard' and 'Lenient' treatments respectively, implied by the lack of a $P$ value between them. Likewise LAI (leaf area per unit ground area) was reduced $(\mathrm{P}<0.01)$ from LAI 4.6 (Nil), to LAI 1.0 ('Lenient') and LAI 0.6 ('Hard') (Table 2).

Table 1 Effect of three levels of grazing on herbage mass on October 23, and on seed yield the following 25 February 1986 , of five subterranean clover cultivars.

\begin{tabular}{ccc}
\hline Grazing intensity & $\begin{array}{c}\text { Seed yield } \\
(\mathrm{kg} / \mathrm{ha})\end{array}$ & $\begin{array}{c}\text { Herbage mass } \\
\text { (kg DM/ha) }\end{array}$ \\
\hline Nil & $1254 \mathrm{a}$ & $5587 \mathrm{a}$ \\
Lenient & $324 \mathrm{a}$ & $1613 \mathrm{~b}$ \\
Hard & $71 \mathrm{~b}$ & $1405 \mathrm{~b}$ \\
\hline
\end{tabular}

Differing lower case letters denote a significant difference at $\alpha=0.05$ based on least significant difference tests.

Table 2 Leaf parameters of five subterranean clovers under three levels of grazing measured 23-25 October 1985.

\begin{tabular}{lcccc}
\hline & \multicolumn{4}{c}{ Grazing intensity } \\
\hline Nil & Lenient & Hard & Signif. \\
\hline Leaf area index & $4.64 \mathrm{a}$ & $1.07 \mathrm{~b}$ & $0.65 \mathrm{~b}$ & $* * *$ \\
Leaf area/plant $\left(\mathrm{cm}^{2}\right)$ & $42.85 \mathrm{a}$ & $9.94 \mathrm{~b}$ & $6.02 \mathrm{~b}$ & $* * *$ \\
Area/leaf $\left(\mathrm{cm}^{2}\right)$ & $3.85 \mathrm{a}$ & $3.58 \mathrm{a}$ & $2.99 \mathrm{~b}$ & $* * *$ \\
Specific leaf area & $127.8 \mathrm{a}$ & $118.8 \mathrm{~b}$ & $100.2 \mathrm{c}$ & $* * *$ \\
Leaf area ratio & $76.00 \mathrm{a}$ & $75.06 \mathrm{a}$ & $45.06 \mathrm{~b}$ & $* * *$ \\
\hline
\end{tabular}

Differing lower case letters denote a significant difference at $\alpha=$ 0.05 based on least significant difference tests.

The production of seed (Table 1 ) was reduced $(\mathrm{P}<0.01)$ from $1254 \mathrm{~kg} /$ ha where there was no grazing, to $71 \mathrm{~kg} / \mathrm{ha}$ by the 'Hard' treatment.

Weight per plant was strongly correlated $(r=0.72$ $\mathrm{P}<0.01$ Table 4) with seed yield. Grazing reduced $(\mathrm{P}<0.01)$ plant weight to $23 \%$ of the ungrazed weight with no difference between severity of grazings (Table $3)$. Weight of leaf per plant, and weight of leaf per unit ground area (Table 3) were not affected by grazing.

Leaf area per plant (Table 2) was strongly correlated $(\mathrm{r}=0.61 \mathrm{P}<0.01$ Table 4$)$ with seed production and was reduced $(\mathrm{P}<0.01)$ to between $24 \%$ and $14 \%$ of the ungrazed values by grazing.

Plants in grazed treatments had thicker leaves, as indicated by the specific leaf area (SLA- area per one gram leaf weight) data. SLA was reduced $(\mathrm{P}<0.01)$ by both grazing treatments (Table 2), and was strongly correlated $(\mathrm{r}=0.70 \mathrm{P}<0.01$ Table 4$)$ with seed yield.

Area per leaf (Table 2) was reduced by the 'Hard' grazing treatment $(\mathrm{P}<0.01)$, to $78 \%$ of the ungrazed value, and was highly correlated $(\mathrm{r}=0.60 \mathrm{P}<0.01$ Table 4) with seed yield. The leaf area ratio (LAR-leaf area per unit plant weight) was substantially reduced (P <0.01) by the 'Hard' treatment to $59 \%$ of the ungrazed value (Table 2), whilst the LAR following 'Lenient' grazing was little affected. LAR was also correlated ) with seed yield ( $\mathrm{r}=0.55 \mathrm{P}<0.05$. Table 4$)$.

The number of leaves per unit ground area was severely reduced $(\mathrm{P}<0.05)$ by both Lenient and Hard treatments (Table 3 ) to $25 \%$ and $18 \%$, respectively, of the ungrazed value and was correlated $(r=0.52 \quad \mathrm{P}<0.05$ Table 4$)$ with seed yield.

The mean plant population was 1080 plants $/ \mathrm{m}^{2}$ and did not differ with treatment.

Individual leaf weight (Table 3 ) was increased $(\mathrm{P}<0.01)$ by $18 \%$ to $25 \%$ in grazed treatments. The numbers of burrs present (Table 3) were severely reduced $(\mathrm{P}<0.01)$ by grazing to $16 \%$ and $10 \%$ of the ungrazed value ( 'Lenient' and 'Hard' treatments respectively), and were correlated $(\mathrm{r}=0.56 \mathrm{P}<0.05$ Table 4$)$ with seed yield. Inflorescence numbers (Table 3 ) were progressively reduced to $22 \%$ and $9 \%$ by 'Lenient' and 'Hard' treatments respectively $(\mathrm{P}<0.01)$, although the correlation with seed yield was not significant.

The length of runners per unit area (Table 3) was severely reduced $(\mathrm{P}<0.01)$ to $38 \%$ and $25 \%$ by 'Lenient' and 'Hard' treatments respectively, and was correlated with seed yield $(r=0.58 \mathrm{P}<0.05$ Table 4$)$.

\section{Discussion}

\section{The influence of leaf}

Hard continuous grazing during the flowering and seed maturation period reduced seed production to 
Table 3 Weight and number of leaves, runners and reproductive structures of five subterranean clovers under three levels of grazing measured 23-25 October.

\begin{tabular}{lcccc}
\hline & \multicolumn{2}{c}{ Grazing intensity } \\
\hline & Nil & Lenient & Hard & Signif \\
\hline Weight/plant $(\mathrm{g})$ & $0.56 \mathrm{a}$ & $0.13 \mathrm{~b}$ & $0.13 \mathrm{~b}$ & $* * *$ \\
Weight/leaf $(\mathrm{g})$ & $0.014 \mathrm{~b}$ & $0.057 \mathrm{a}$ & $0.079 \mathrm{a}$ & $* * *$ \\
Weight of leaf/unit ground area $\left(\mathrm{g} / 0.01 \mathrm{~m}^{2}\right)$ & 3.63 & 0.91 & 0.65 & $\mathrm{~ns}$ \\
Weight of leaf/plant $(\mathrm{g})$ & 0.34 & 0.08 & 0.06 & $\mathrm{~ns}$ \\
Number of leaves/unit area $\left(\mathrm{no} / 0.01 \mathrm{~m}^{2}\right)$ & $121.0 \mathrm{a}$ & $30.2 \mathrm{~b}$ & $21.7 \mathrm{c}$ & $* * *$ \\
& & & & \\
Inflorescences $\left(\right.$ no/0.01 $\left.\mathrm{m}^{2}\right)$ & $58.1 \mathrm{a}$ & $12.9 \mathrm{~b}$ & $5.5 \mathrm{c}$ & $* * *$ \\
Burrs (no/0.01 $\left.\mathrm{m}^{2}\right)$ & $74.4 \mathrm{a}$ & $12.2 \mathrm{~b}$ & $7.2 \mathrm{~b}$ & $* * *$ \\
Potential sites for reproductive structures $\left(\mathrm{no} / 0.01 \mathrm{~m}^{2}\right)$ & $121.0 \mathrm{a}$ & $30.2 \mathrm{~b}$ & $21.7 \mathrm{c}$ & $* * *$ \\
Total length of runners $\left(\mathrm{cm} / 0.01 \mathrm{~m}^{2}\right)$ & $64.9 \mathrm{a}$ & $24.7 \mathrm{~b}$ & $16.5 \mathrm{c}$ & $* * *$ \\
\hline
\end{tabular}

Differing lower case letters denote a significant difference at $\alpha=0.05$ based on least significant difference tests.

Table 4 Correlations between plant attributes on 23-25 October 1985 and seed yield on 25 February 1986 of five subterranean clovers under three grazing regimes.

\begin{tabular}{lc}
\hline Plant attribute & $\begin{array}{c}\text { Correlation } \\
\text { coefficient }\end{array}$ \\
\hline Weight per plant & $0.72^{* *}$ \\
Specific leaf area & $0.71^{* *}$ \\
Area of leaf per plant & $0.61^{* *}$ \\
Area per leaf & $0.60^{*}$ \\
Total length of runners per unit area & $0.58^{*}$ \\
Total plant weight per unit area & $0.57^{*}$ \\
Number of burrs per unit area & $0.55^{*}$ \\
Leaf area ratio & $0.55^{*}$ \\
Leaf area index & $0.52^{*}$ \\
Number of leaves per unit area & $0.51^{*}$ \\
\hline
\end{tabular}

Significant levels of probability are indicated by ${ }^{*} \mathrm{P}<0.05,{ }^{* *} \mathrm{P}<0.01, \mathrm{n}=20$.

only $6 \%$ of the yield where there was no grazing, or $22 \%$ of the yield where grazing was more lenient.

Several studies have shown an increase in seed yield in response to defoliation (Rossiter 1972; Collins 1978; Collins 1981; Collins et al. 1983), defoliation and grazing (Rossiter 1961) or grazing alone (Rossiter \& Park 1972; Bolland 1987) up to first flower appearance, generally as a result of increased numbers of flowers being produced in the more favourable light regime. However, grazing or defoliation after first flower appearance and during the flowering period (Rossiter 1961; Collins 1978; Collins et al. 1983) decreased seed yield, even though grazing or cutting height was adjusted to avoid removal of flowers. Archer (1990) recorded a $75 \%$ reduction in seed yield to $310 \mathrm{~kg} / \mathrm{ha}$ when plants were defoliated to $3 \mathrm{~cm}$ every 2 weeks. He noted that flowers were removed, although this loss was not quantified.

Clearly a loss of flowers and a reduction of green herbage may both be involved in reduced seed production. In the present investigation grazing reduced herbage mass to $25-29 \%$ of the ungrazed level, yet seed yield from the 'Hard' grazed treatment was much more severely reduced (Table 1). The high correlation of weight per plant with seed yield suggests that lack of substrate for production may be a cause, especially since runner length was reduced to a similar degree, and was correlated with seed yield. Whilst not weighed, they would have accounted for much of the loss of weight per plant.

Grazed plants suffered a substantial $76-86 \%$ loss of leaf area (which in turn would have inhibited productivity) and was also correlated with seed 
production. Whilst the Hard treatment substantially reduced the LAR, it was not reduced by the 'Lenient' treatment. It is likely that leaf loss in the 'Hard' treatment would have both increased the proportion of photosynthate required for maintenance, and decreased absolutely, that available for seed production, accounting for the greater impact of this treatment on seed yield.

Specific leaf area measurements were strongly correlated with seed production, and showed that leaves became thicker with grazing, a consequence noted by Blackman et al. (1955). This has important implications for photosynthetic efficiency, since the rate of carbon fixation is related to leaf area, whereas respiratory usage of fixation products is related to biomass (Acock et al. 1971). Consequently, plants in the 'Lenient' and 'Hard' treatments had thicker leaves operating at a lower level of efficiency. This, plus the large reduction in LAR associated with the Hard treatment are probably the main physiological reasons for the low seed yield of $71 \mathrm{~kg} / \mathrm{ha}$.

\section{Reproductive structures}

Grazed treatments exhibited a substantial reduction in the numbers of inflorescences and burrs at the time of sampling. Rossiter (1976) found that when subterranean clover swards were defoliated early in the flowering period, numbers of leaves and flowers were very closely correlated. In the present study, a comparison of the total numbers of flowers and burrs counted, with the numbers of potential sites for these structures in the axils of leaves (Table 3), showed that $83 \%$ of potential sites were occupied under the 'Lenient' treatment, but only 58\% under 'Hard' grazing. Although this accelerated reduction in inflorescences and burrs may be partly due to the lowered photosynthetic capability of the leaf canopy, it is assumed that grazing animals consumed a considerable proportion of the flowers and burrs already formed. Peduncles were not counted at sampling and hence it is not possible to quantify this assumption. Reduced numbers of floral structures following grazing by sheep were recorded by Stockdale \& Kelly (1989) and Rossiter \& Park (1972), while the latter authors suggested sheep selectively removed burrs during the period of flowering and seed set.

\section{General considerations}

An "acceptable level" of seed production to provide an adequate plant population for subterranean clover to provide an adequate plant population subsequently has seldom been defined in Australian or New Zealand research literature. Recently Dear et al. (1993) maintained that seed reserves of early midseason flowering cultivars should be at least $500 \mathrm{~kg} /$ ha. Smetham (2003) proposed theoretical figures of $330 \mathrm{~kg} /$ ha for early, $290 \mathrm{~kg} / \mathrm{ha}$ for mid-season, and 220 $\mathrm{kg} / \mathrm{ha}$ of seed for late flowering cultivars as minima for seed set.

It is clear that the $71 \mathrm{~kg} / \mathrm{ha}$ of seed produced under the 'Hard' treatment of the investigation reported here is insufficient.

\section{Conclusions}

- Continuous grazing of subterranean clover swards below $1600 \mathrm{~kg} \mathrm{DM} / \mathrm{ha}$, equivalent to a leaf area index of 1.0 (approximately one layer of leaf over the runners), during flowering and seed maturation, will reduce seed yields to well below that required to ensure an adequate seedling population by next autumn.

- The reduction of seed production with severe grazing was due to reduced weight per plant and a reduction in leaf area, and probably also due to the removal of substantial numbers of inflorescences and burrs by the grazing animals.

\section{Acknowledgements}

We thank several biometricians-Brian Cullis, Neil Coombes and Warwick Lill-from the Agricultural Institute, Wagga Wagga, and Richard Sedcole from Lincoln University who helped with the analyses, and also the technicians and seed production personnel from N.S.W. Agriculture who helped process the field samples.

M.L. Smetham especially thanks Dr Howard H. Dengate, Director of the Agricultural Research Institute, Wagga Wagga, for permission to use all facilities at the Institute while on study leave.

\section{REFERENCES}

Acock, B.; Thornley, J.H.M.; Warren Wilson, J. 1971. Photosynthesis and energy conversion. Chapter 4. In: Potential crop production. Ed. Waring, P.F. Heinman, London.

Archer, K.A. 1990. The effects of moisture supply and defoliation during flowering on seed production and hardseededness of Trifolium subterraneum L. Australian Journal of Experimental Agriculture 30: 515-522. 
Blackman, F.E.; Black, J.N.; Kemp, A.W. 1955. Physiological and ecological studies in the analysis of plant environment. An analysis of the effects of seasonal variation in daylight and temperature on the growth of Helianthus annuus in the vegetative phase. Annals of Botany (NS) 19: 527-547.

Bolland, M.D.A. 1987. Seed production of Trifolium subterraneum ssp. subterraneum and brachycalycinum as influenced by soil type and grazing. Australian Journal of Experimental Agriculture 27: 539-559.

Carter, E.D.; Cochrane, M.J. 1985. The poor clover status of dairy pastures in the Adelaide hills. pp. 217-219. In: Proceedings of the 3rd Australian Agronomy Conference.

Carter, E.D.; Wolfe, E.C.; Francis,C.M. 1982. Problems of maintaining pastures in cereal-livestock areas of southern Australia. pp. 68-82. In: Proceedings of the 2nd Australian Agronomy Conference.

Collins, W.J. 1978. The effect of defoliation on inflorescence production, seed yield and hardseededness in swards of subterranean clover. Australian Journal of Agricultural Research 29: 789-801.

Collins, W.J. 1981. The effects of length of growing season with and without defoliation on seed yield and hardseededness in swards of subterranean clover. Australian Journal of Agricultural Research 32: 783-792.

Collins, W.J.; Rhodes, I.; Rossiter, R.C.; Palmer, M.J. 1983. The effect of defoliation on seed yield of two strains of subterranean clover grown in monoculture and in binary mixtures. Australian Journal of Agricultural Research 34: 671-679.

Conlan, D.J.; Dear, B.S.; Coombes, N.E. 1994. The effect of grazing intensity and number of grazings on herbage production and seed yield of Trifolium subterraneum, Medicago murex and Ornithopus compressus. Australian Journal of Experimental Agriculture 34: 181-188.

Dear, B.S.; Cregan, P.D.; Murray, G.M. 1993. Comparison of the performance of subterranean clover cultivars in southern New South Wales I. Persistence, productivity and seed yields. Australian Journal of Experimental Agriculture 33: 581-590.

de Koning, C.T.; Carter, E.D. 1989. Losses of subterranean clover seed from dry pasture residues during grazing by sheep in summerautumn. p. 408. In: Proceedings of the 5th
Australian Agronomy Conference.

Fukai, S.; Silsbury, J.H. 1976. Responses of subterranean clover communities to temperature. I. DM production and plant morphogenesis. Australian Journal of Plant Physiology 3: 527543.

Hochman, Z.; Osborne, G.J.; Taylor, P.A.; Cullis, B. 1990. Factors contributing to the reduced production of subterranean clovers on acid soils. Australian Journal of Agricultural Research 41: 668-682.

Rossiter, R.C. 1961. The influence of defoliation on the components of seed yield in swards of subterranean clover (Trifolium subterraneum L.). Australian Journal of Agricultural Research 12: 821-833.

Rossiter, R.C. 1966. The success or failure of strains of Trifolium subterraneum L. in a Mediterranean environment. Australian Journal of Agricultural Research 17: 425-446.

Rossiter, R.C. 1972. The effects of defoliation on flower production in subterranean clover. Australian Journal of Agricultural Research 23: 427-435.

Rossiter, R.C. 1976. The effects of defoliation on vegetative growth in swards of three strains of subterranean clover. Australian Journal of Agricultural Research 27: 197-206.

Rossiter, R.C.; Park, R.J. 1972. The effect of stocking rate and defoliation on relative seed production of a mix of two subterranean clover cultivars. The Journal of the Australian Institute of Agricultural Science 38: 209-211.

Smetham, M.L. 2003. A review of subterranean clover (Trifolium subterraneum L.); Its ecology and use as a pasture legume. Advances in Agronomy 79: 303-350.

Stace, H.C.T.; Hubble, G.D.; Brewer, R.; Northcote, K.H.; Sleeman, J.R.; Mulcahy, M.J.; Hallsworth, E.G. 1968. A handbook of Australian soils. Rellim Technical Publications, Glen Side, South Australia. CSIRO, Canberra. 435 pp.

Stockdale, C.R.; Kelly, K.B. 1989. Effects of defoliation on subterranean clover seed production. pp. 417420. In: Proceedings of the 5th Australian Agronomy Conference.

Young, R.R.; Morthorpe, K.J.; Nicol, H.I.; Croft, P.H. 1994. Effect of sowing time and grazing on the dry matter yield, phenology, seed yield and hardseed levels of annual pasture legumes in Western New South Wales. 